Journal of Management and Economic
Studies
2019, 1(2): 35-42 DOI: $10.26677 / \mathrm{TR} 1010.2019 .71$
Journal Homepage: https://www.jomaes.org

\title{
The Factors That Impaired African Development: A Nigerian Historical Perspective
}

\author{
Salisu Ahmed Kabiru \\ Public Administration Department, Umaru Musa Yar'dua University, Katsina, Nigeria.
}

\author{
Rozita Arshad \\ School Of Government, University Utara Malaysia.
}

\begin{abstract}
The purpose of this paper was to examine the the factors that impairs African development such as slave trade, colonization, neocolonization and corruption which played a vital role in stagnating African development. This study is conceptual one, utilizing secondary source of data, and the method of analysis was analytical. This study revealed that apart from slave trade, colonialism and neo-colonialism, corruption is the most devastating factor that stagnate African development. The study recommends that corruption should be fought from all angles and severe punishment should be meted on corrupt officials. This study argues that African underdevelopment could be traced to slave trade era where about 15-20 million of able bodied men and women were carted away from Africa to Europe and subsequently to America. Africans were colonized and their mineral resources were exploited, and in order to continue the exploitation of the African resources neo-colonialism was introduced through their stooges and multi-National Corporations. The African leaders on their part embezzled public funds which has greatly affected the development effort negatively.
\end{abstract}

Keywords: African Development, Historical Perspective, Nigerian

\section{Introduction}

Development according Anyebe (2014) implies progression from lower level to higher level in terms of quality of life of a country, it is an improvement which emanate from economic growth, increase in GDP as well as increased in per capita income, while underdevelopment implies under-utilization of socio-economic potential which result to stagnating the development of the a country in terms of access to job opportunities, health care, drinkable water, food, education and housing, and infrastructure.

No society that does not want to development at all ages right from the Stone Age to this era. Human beings are not static but rather, they are dynamics. They changes from time to time for 
the improvement of their socio-economic life. Before the start of salve trade in African, Rodney (1972) argued that in the 16th century even though there was technological gab between Europe and Africa, the gab was not substantial as both were using Iron Age technology. The only advantage the European had over Africa then, was on ship building which was used so intensively in the shipping slaves from Africa to America and Europe. This inhuman practice was responsible for the depopulation of at that time while at the same time it increased the population of the Europeans as well as improve their economy substantially and making the development of Africa to be stagnated. This led to the proliferation of all sort of problems such as poverty, and unemployment which stands at $60 \%$ and $40 \%$ as well as proliferation of diseases which could also be attributed to the stagnation of African development. Slave trade marked the beginning of African undevelopment followed by other factors such as colonization, imperialism, decolonization and economic colonization.

\section{Objective/Problem Statement}

The objective of this study is to examine the factors that impede African development in the past and in the present era. The problem of this study is what are the causes of African undevelopment. Africa is lagging behind in terms of development compare to Europe, America and Asia economically, politically and technologically and this is a serious problem that plaque the continent where more than $70 \%$ of the population are living below the poverty line, unemployment is also on the increase shooting to $40 \%$, hospital lack basic equipment, most road are dilapidated, power supply very elliptic, all these are as a result of stagnated development as caused by the factors enumerated such as slave trade, and corruption.

\section{Literature Review}

Development and underdevelopment are two concepts that are not easily reducible to a single and universally acceptable or applicable definition, but rather it can be view in a manner of what one values as the economic or social goal of development. Development can only be studied in a multidimensional fashion, first as a process involving the entire economic and social institutions and not only by the economic growth through postulation of gross national product and secondly, as an overall social process that is dependent upon the outcome of man's effort to deal with his natural environment.

Development could therefore be define as involving the mobilization and utilization of the resource of the society for the betterment or benefit of all member of the society. What can be digested from this definition is that, any meaningful development strategy should accelerate radical changes in the political, economic, and administrative structures while at the same time, reduces inequality and eradicate poverty in the society. According to Walter Rodney (1972), development in human society is a many-sided process. At the level of the individual, it implies increased skills and capacity, greater freedom, creativity, self -discipline, responsibility and material well-being.

Based on this back drop it is difficult to analysis development using single theory as that will not capture the whole factor that were responsible for the under-development. Starting from slave trade to colonialism. The multi-dimensional aspect of underdevelopment compel one to use multi-dimensional approach in studying and analyzing underdevelopment where one has to use a combination of theory and concepts such as corruption in order to analysis underdevelopment.

Slave trade was responsible for carting away the youth from Africa to America which caused the stagnation of African development at that particular period as these youth who were 
supposed to serve as the agent of development at that period but taken away to America leaving the continent with the elderly persons.

After slave trade was abolished the European now turned to colonization which is defined as political and economic domination of one nation over another nation. A round the $19^{\text {th }}$ century most of the countries in Africa were under the Europeans domination, their mineral resources were exploited and taken to Europe to serve their industries as raw materials and later return the processed product to Africa and sell it or exchange in an unequal manner. This unequal exchange has greatly impaired African development at particular time as Africans were made to be supplier of raw materials to the Europeans industries without making any effort to development the African industries.

Neo-colonization is an extension of colonization in another form which is not direct domination politically but it an indirect domination economically. The African were made to be subservient of multi-nation corporations of the world such as World Bank and IMF, through these corporations the Europeans were able to continue their domination of the African people by dictating to them what policy they should pursue in order to develop which in most instances are detriment to the African development example Sap In Nigeria was introduced as dictated by the World Bank.

Corruption is the misappropriation of fund meant for particular purpose especially by the government official. This phenomenon is what is affecting Africa now and it has serious consequence on African development. For instance, about 200 billion US dollar was alleged to have been stolen by the government officials from 1999 to 2015, this amount of money is enough to build about 100 city model as in china 1 billion was spent in building a city model that has all what a modern city needs in terms of infrastructural facilities.

\section{Theoretical Framework}

The historical 'dialectical materialism' propounded by Karl Marx 1887, argued that people are both the producers and product if society. They are the architects of their society and themselves by their own very action, that is, history is a process of human self-creation. He further argued that through historical perspective the process through which humanity produces event and is in turn produced by social reality (Haralambos \& Holborn, 2000).The society can be view as a whole with various parts as interdependent which influences each other that the economic sector plays the most influential role in shaping society quest for development, which dialectical materialism put emphasis on historical economic perspective in explaining phenomenon in a society (Spencer,2013). From this theory we can only understand the factors that impaired African development by going back to history which help in explaining these factors

\section{Methodology}

This study employed conceptual approach, as such secondary source of data collection was used such as books, journal, and other print materials, and an analytical inductive method of data analysis was also employed for the analysis.

\section{Analysis of Factors That Impairs African Development}

\subsection{Slave Trade}

Slave trade is one the factors that impairs African development right from 1400 to 19 century, when the business was abolished. According to Rodney (1972) Africa was the cradle of civilization, such that, as at fourteenth century, African civilization has reached a kind of apogee in terms of technological innovation. Coupland (1939) adds "African black smiths knew 
how to refine gold, copper, bronze and even iron, as early as the time of Christ. This African civilization according to him surpassed the oceanic civilization in technical development.

However, the race for slaves retarded development in every society that experience it, for example, The Brazil contact with the Europeans virtually exterminate the Indians as well as their relative development. Africa was seriously depopulated as a consequence of the slave trade. Slavery involved carting away of able-bodied men and women who constituted the active sector of the population. Between 10 to 20 million men and women were estimated to have been carted away from the continent of African. This Massive lost to the Africa labor was made more critical because it composed of able-bodied men and young women. African economic activity was affected both directly and indirectly by depopulation (Lovejoy, 1982).

The damaging effect of the slave trade went much further as internal wars became profitable and multiplied, thereby blocking political and economic development as well, stagnating technological innovations both directly and indirectly. The removal of millions of Africans young adults who constituted human agents of scientific and technological invention, as a result of European slave trade, represented a direct block to African advancement. The Europeans traded with Africans on an un-equal basis, they would have brought them in exchange for Africans products, carts, and wheel material which could increase production, they should have provided education and training of simple art of harnessing oxen, instead of searching for slaves (Anstey \& Curtins, 1968).

\subsection{Colonialism}

After slave trade is the next factor that impairs African development was colonization which was imposed on most African countries and some Asians in the $19^{\text {th }}$ century. Colonialism is a situation where one country exercises political domination over another by assuming control of the machinery of government and directing the affairs of society (Eke,1988). Many of the colonized societies became colonized after they had been cajoled into ceding their territories through the signing of the treaties, while many others were out-rightly subdued and subjugated through superior weapons of the European. Some of these colonizing European powers include; Britain, Spain, Portugal and France. Nwako (2010), argues that "colonialism is a direct form of imperialism which is why it is often said all colonialism is imperialism but not all imperialism is colonialism".

The colonial adventure started about 1800 up to 20th century following the abolition of slave trade. A number of factors were responsible for colonialism the most important of which was the economic factor. The emergence of industrial revolution which was made possible by slave labor meant that the slave had accomplished their historical mission of helping Europe achieved capitalist development. The industrialization of Europe led to increase production of manufactured goods without commensurate market. In addition to this, progress in industrial sector was moving faster than progress in agriculture and it became difficult for agriculture to satisfy the demand of industry for raw materials (Alemazung, 2010; Nun, 2011).

A number of steps were taken by the colonizing European power to guarantee the maximization of their economic interest, through the exploitation of the colonized territories. The first step was to subjugate the African kings and force them to work for the interest of the colonialist, and to confiscate, or to take out of Africans whatever land they wanted, and simultaneously assembled African labour to mine the land for gold, copper, diamond, asbestos, tin, iron, and zinc or to farm it for wool, cattle, tobacco, timber, sugar, bananas, coffee, cashew, sisal, palm oil, kernel, cotton, cocoa, rubber and groundnut. Another step was, that those Africans who felt reluctant to disposes their land and unwilling to work for the Europeans were confiscated and compel to work for the Europeans. The exploitation of the Africans and their 
mineral resources by the Europeans was one of the major factors that retarded African development as the resources that should have been used for the development of African was taken to Europe exploitatively (Agbor,2011; River-Santos,2015).

\subsection{Neo-Colonialism}

Neo-colonialism is a term that members of the political left and post dependency theorist used to describe the dominance of strong nation over weak nation not by direct political control as in colonization but by economic and cultural influence. This act is leveled against trans-national corporations and government of the western world especially the U.S.A and its allies. (Hountondji,1995).

It is further described as a form of contemporary economic imperialism in which both previous colonizing states and other power states maintain continuing presence on the economies of former colonies especially as it concern raw materials exploitation. Strong nation thus, charge with interfering in the governance and economies of the weaker nation to maintain the flow of such raw materials at prices and condition unduly beneficial to the developing nation and their trans-national corporations (Langmia,2011). Post-colonial writers holding this view further point to the fact that Africa pays more money annually in debt service to the international monetary fund (IMF) and World Bank, than it receives in loans from them, thereby depriving the inhabitants of those countries necessities of life. This dependency allows the (IMF) and World Bank to impose structural adjustment plan upon these nations. These adjustments strategies largely imply privatization programmes which results in the selling of public assets to few individuals and foreign corporation at the detriment of the masses which a company with it the deteriorating of the living standard of the citizenry. (Nzau, 2010).

Neo-Colonization is the latest instrument used by the developed countries in maintaining their dominance over the developing nations through economic manipulation and maneuvering. For example the current oil slide was predetermine in order to stagnate developing countries drive for development which is posing a threat to the developed world as they are facing stiff competition especially from the BRICS countries. Why is it that there was never a time that the price of weapons slide, it is always going up because they monopolized the manufacturing and selling of the weapons, on this, they make market stable at all time for their exploitative gains. These weapons are mostly sold to the developing countries especially the Africans in order to stagnate their development because no nation can make any meaningful development when there is internal or external crisis and this what is happening in Africa now ,for example the crisis in Sudan, Nigeria ,Libya, and Democratic Republic of Congo (Omotola, 2009).

\subsection{Corruption}

Corruption embraces a broad spectrum of activities ranging from fraud, theft, through misrepresentation, embezzlement, and misappropriation of corporate or public funds to bribery, payment made in order to gain advantage or to avoid a disadvantage. Corruption according to Thomas (1999) 'affects any polity in a negative manner. Its effect are particularly acute in emerging economy and worse-off for endemically corrupt polity, which according to him, no positive change and economic growth cannot possibly occur.

Corruption is a universally declaimed, and constitutes a phenomenon in itself and is invariably the output of a conglomeration of discrete failures. A failure of institutional control over the bureaucrats, or a failure of legal system that climax the behavior of those who perpetrate the crime (Akay, 2006) .Isa (2012), advances that "corruption is a system of deep institutional weaknesses and leads to inefficient economic, social and political outcomes. It reduces economic growth, retards long term foreign and domestic investment, enhances inflation, 
depreciates national currency, and reduces expenditure for education and health, increases military expenditures, misallocate talent to rent-seeking activities, pushes firms underground, distorts-market and the allocation of resources, increases income inequality and poverty, reduces tax revenue, increase child mortality rates, distorts the fundamental role of government on enforcement of contracts and protection of property".

Corruption may take a varied forms or dimensions but, state corruption otherwise Called grand corruption or political corruption stands out as the progenitor of all its other forms .Others include - pretty or bureaucratic corruption, electoral corruption, bribery, fraud, embezzlement, extortion, nepotism and cronyism new patrimonialism .Corruption kills development, nothing is as destructive to a society as to the rush to quick and easy money which makes fools of those who can work honestly and constructively. The grand corruption is what retard Nigerian development drive, as fund meant for developmental effort were carts away by government officials, for example the Minister of Information of Nigeria reported that about 55 public officials allegedly stole 1.34 trillion naira between 2006 to 2013.This amount of money stolen by government officials is enough to fixed a modern rail way line that can connect all the 36 states, fixed the energy sector, and also fixed the dilapidated roads, as well as fixing the other infrastructures that are vital to the development of the country.

\section{Findings/Discussion}

Findings indicated that slavery, colonization and imperialism are the genesis of African underdevelopment, and corruption is the cancer that impedes Africa from being developed. Going by findings this paper argues that slave trade was the starting point of impeding African development as the youth who were the agent of development were taken away from Africa to other continent for slavery work. After slavery then came colonization which significantly stagnated African development for European development. Then subsequently neocolonization which is regarded as a revision of form and method of control for the reproduction of old dependency relation whereby an independent state is only independent by names not in the actual meaning of it as the state is being dictated on what do and how to do it. Corruption is the current factor that deter Africa from attaining a reasonable level of development as corrupt of officials embezzled fund meant for development purposes.

\section{Conclusion/Implication}

Conclusively the highlighted factors such slave trade colonization and decolonization were some of the factors that impair African development from 1440 to this era. This unequal and exploitative relationship which produces developments in the capitalist and underdevelopment in Africa is explained via historical perspective from slave trade to colonization and neocolonialism.

This paper posits that the implication of alleged fund stolen by public officials which enough to build the nation infrastructures such as road, electricity, and pipe born water has a serious implication for the development of the country and should not be allow to go unpunished, culprit must be brought to book, and the stolen fund must also be recovered, if not the menace will continue as there is no deterrent mechanism to stopped it. Public stealing is presently the most devastation factor that prevents Africa from developing, as all aspects of the society are infected by corrupt practices and this is why it is very difficult to plan and execute any meaningful developmental strategy without it being hijacked by corrupt official either in the initial stage or in the implementation process for their own interest, If in the past we were enslaved and colonized, but now we are no more under such domination. Another implication was when corrupt officials collaborate with foreign government and multi-national corporations to squander African resources and by extension impede its developmental process 
unless such leaders are flush out of power corridor the African predicament of undevelopment will remains for a long time to come without being solved. This paper posits that it is within the ambit of the independent state and its political elite to repudiate the maneuver and move the continent forward.

\section{Recommendation}

-The Europeans must be made to take full responsibility for under development of Africa and must be made to compensate the Africans by transferring technology to Africa as they did to Japan under the Marshall plan of 1945 as compensation for the atomic bomb catastrophe.

-The entire society should fight corruption from its entire dimensions with commitment and courage. Nobody should be spared no matter how highly placed he is in the government.

-Formulation of indeneous development plans providing for maximum mobilization and effective use of domestic resources without depending on foreign nations

-An instillation of effective mechanism for resisting foreign domination from all ramifications.

\section{References}

Agbor,J. A.(2011).How does colonial origin matter for economic performance in sun-saharan Africa. World Institute for Development Economic Research working paper 2011/27.

Akay,S.( 2006).The menance of corruption to society.Ibadan:University Press

Alemazung,J.A, J.A.(2010).Post colonialism: An analysis of internal factors and political marring African socio-economic and political development. Journal of African Studies 3.(10).

Anstey, R. T. (1968). Capitalism and Slavery: a Critique1. The economic history review, 21(2), 307320.

Anyebe,A.A.(2014).Reading in development administration Zaria: Salami Publishers

Coupland, R. (1939). The exploitation of East Africa, 1856-1890: the slave trade and the scramble.

Curtin, P. D. (1968). Epidemiology and the slave trade. Political Science Quarterly, 83(2), 190-216.

Eke,P.(1988).Colonialism an epochal. Journal of African Studies 16, (1).3456-3465

Haralambos, M., \& Holborn, M. (2000). Themes and perspectives.London: Collins Educational.

Hountondji, P. J. (1995). Producing Knowledge in Africa Today the Second Bashorun MKO Abiola Distinguished Lecture. African Studies Review, 38(03), 1-10.

Igboin,B.O.(2011).Colonialism and african cultural values.African Journal of History and Culture 3,(6),96-103.

Igwe ,S. C. (2010) How African Underdeveloped Africa. Port-Harcourt: professional granter and publishers.

Isa, L. B.(2012).A perspective on currption:the Nigerian experience. Journal of Administrative Studies, 2 (2).

Langmia, K. (2011). The secret weapon of globalization: China's activities in sub-Saharan Africa. Journal of Third World Studies, 28(2), 41.

Lovejoy, P. E. (1982). The volume of the Atlantic slave trade: A synthesis. The Journal of African History, 23(04), 473-501. 
Marx, K. (1887). Capital. A critique of political economy. The process of production of capital. Moscow, RU: Progress Publishers.

Nun,N.J.\& Wantchekon,L.(2011).The slave trade and the origin of mistrust in Africa. American Economic Review, 101,3221-3252

Nwankwo, P. O., \& Nwankwo, P. O. (2010). Criminal justice in the pre-colonial, colonial and post-colonial eras: An application of the olonial model to changes in the severity of punishment in Nigerian law. USA: University Press of America.

Nwankwo, R. N. (2013). Official corruption and poverty reduction in Nigeria: A critical assessment 2003-2010. International Journal of Arts \& Sciences, 6(2), 305.

Nzau, M. (2010). Africa's Industrialization Debate: A Critical Analysis. Journal of Language, Technology \& Entrepreneurship in Africa, 2(1), 146-165.

Okereke, O. \& Akpe, A.E. (2002). Development and underdevelopment. Enugu: John Jacob Classic Publishers.

Omotola, J. S., \& Enejo, K. E. (2009). Globalization, world trade organization and the challenges of sustainable development in Africa. Journal of sustainable development in Africa, 10(4), 268-289.

River-Santos, M.et al (2015). Social entrepreneurship in sub-saharan Africa .Retrived from UvADARE, the institutional repository of the University of Amsterdam (UA) http://hdl.handle.net/11245/2.164866

Rodney, W. (1972) How Europe underdeveloped Africa. Abuja: Panat Publishing

Spencer, P. E. (2013). History and development of slave trade. Developmental Studies 49,(1),15-20

Thomas, N. (1999). Possessions: Indigenous art, colonial culture (p. 10). London: Thames and Hudson. 